\title{
Analysis of Early Given Breast Milk Complementary Foods in Baby Age 0- 6 Month at Larangan Health Public Center in Health Departement of pamekasan
}

\author{
Nur Khalilah', \\ Nurwijyanti ${ }^{2}$, \\ Nurdina ${ }^{2}$ \\ ${ }^{1}$ Magister of Health Study \\ Program of STIKes Surya Mitra \\ Husada Kediri \\ ${ }^{2}$ Lecturer of STIKes Surya Mitra \\ Husada Kediri \\ Email: \\ khalilahhudaifi@gmail.com
}

Received : October 4, 2018

Accepted : October 6, 2018

Published : November 30, 2018

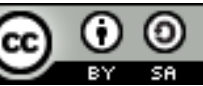

\begin{abstract}
Breast Milk Complementary Foods (MP-ASI) is a supplementary food given to infants other than breast milk after 6 months of age until the age of 24 months. Breast milk complementary foods is given to meet the energy and nutrient needs of infants that are not covered by breast milk. the factors that are suspected to be the cause of mother giving ASI AS early are knowledge, social economy, culture and health cadre role. The purpose of this study was to analyze the factors that influence the provision of early given Breast milk complementary foods in infants aged 0-6 months. The type of this research is quantitative research with analytic observational design with cross sectional. This study was conducted from February to March 2018 at Larangan Health Public Center of Pamekasan with a population of mothers who have babies 0-6 months who provide early Breast milk complementary foods of 86 people. The sample size was 71 respondents, with sampling accidental sampling type. The independent variables are knowledge, socioeconomic, cultural and health cadre's role. The dependent variable is the provision of early Breast milk complementary foods in infants aged 0-6 months. Data were collected using questionnaires. Data were analyzed using test logistic regression with $\alpha=0.05$. The results showed that the variable $\mathrm{X} 1$ (knowledge) with $\mathrm{p}=0.035$; $\mathrm{OR}=3,725$, variable $\mathrm{X} 2$ (social economy) $\mathrm{p}=0,135$; $\mathrm{OR}=4,226, \mathrm{X} 3$ (culture) $\mathrm{p}=0,003$; $\mathrm{OR}=9,973, \mathrm{X} 4$ (role of health cadre) $\mathrm{p}=0,134$; $\mathrm{OR}=2$, 187. So it can be concluded that the factors that affect $\mathrm{Y}$ (provide early Breast milk complementary foods in infants aged 0-6 months) are cultural and knowledge factors, with the most dominant factor is cultural factor with influence of 9.973. Social culture or tradition has a relationship with the provide early Breast milk complementary foods. The mindset of most people still trust it can accelerate the growth of babies by follow the tradition as adherence to parents. So it can affect the knowledge, perception, and attitudes of a person to something, therefore need more intense health promotion efforts again in order to exclusive coverage of exclusive breastfeeding increases.
\end{abstract}

Keywords: Knowledge, socioeconomic, cultural, role of health care, giving of early breast milk complementary foods

Copyright @ 2018 STIKes Surya Mitra Husada All right reserved.

This is an open-acces article distributed under the terms of the Creative Commons Attribution-ShareAlike 4.0 International License. 


\section{INTRODUCTION}

Progress of a nation is influenced and determined from the level of public health, one of which can be seen from the human nutritional status. One efforts to achieve the fulfillment of nutritional status begins with the realization of the golden period in the baby and children, which at that time is a time that requires appropriate nutritional intake so it is expected to grow and develop optimally. To make this, the Global Strategy for Infant and Young Child Feeding, the World Health Organization (WHO) and UNICEF recommend four important things to do namely, first to give breast milk to the infant immediately within 30 minutes after birth, only breast milk alone or exclusive breastfeeding from birth to 6 months of age, the third provides complementary feeding of breast milk from infants aged 6 months to 24 months and the fourth continues breastfeeding until the child is 24 months or more (DEPKES, 2006).

The period of gold that has been described is not only influenced by the intake of nutrition alone because it has long been realized that the behavioral and sociocultural factors are also very influential on the nutritional problems. Negative behavior in the form of dietary restrictions and feeding before age is still met in some areas, especially areas that are poor with information and condensed on the myths. One of these negative behaviors is the provision of complementary feeding (AIAT) foods too early. Breastfeeding Foods (MP-ASI) is an other food given to infants other than breast milk after 6 months old baby until 24 months of age (Sulistyoningsih, 2011). Breastfeeding Food is given to meet the energy and nutrient needs of infants who are not covered by breast milk (Supariasa, 2011).

Nutrition plays an important role in the human life cycle. Lack of nutrition in pregnant women can cause low birth weight (LBW) and can also cause a decrease in the level of intelligence. In infants and children, malnutrition will lead to growth and developmental disorders that if not resolved early can continue into adulthood. But the fact is sometimes cause misunderstanding that is the reason to meet the nutritional needs of infants, then performed the provision of MP-ASI is too early. MP-ASI provide is too early due to lack of experience in breastfeeding mothers who assume that their baby will not be satisfied and will not be able to sleep if only consuming breast milk alone (Irawati A, 2010).

The early phenomenon of MP-ASI also has a high percentage, especially in Indonesia, based on the IDHS in 2012, 4-5 months of infants received early breastfeeding food by 57\%, $8 \%$ were given other milk and $8 \%$ were given water. In addition, the results of research conducted by Irawati (2010) at the Center of Training and Development of Nutrition and Food Ministry of Health, which states that more than 50\% of Indonesian infants get complementary feeding milk before the age of 1 month. Yet as we know that the provision of MP-ASI too early will have a bad impact, one of digestive presence disorders in infants such as diarrhea, vomiting and difficult bowel movements (Cott, 2012). In Madura Island, especially in Pamekasan regency, the provision of early breast milk is still quite high. In 2010, infants who received exclusive breastfeeding $26.47 \%$ of 6,826 babies, but in 2011 the number of exclusively breast-fed infants decreased to $10.96 \%$ from 13,222 infants (Dinkes, Pamekasan, 2011). While data obtained in BPM Siti Huzaimatul Himmah Bugih Pamekasan there are 40 babies and 37 babies are not given exclusive breastfeeding but get the MP-ASI from her mother in the form of lontong and banana, fine pulp and milk formula (Data Bidan Praktik Mandiri IMA, 2017) (Hoiroh , 2017).

The results of preliminary study conducted by the authors in October 2017 through interviews with local midwives the number of babies to October as many as 475 babies with exclusive breastfeeding coverage of 87 babies which means as many as 442 babies have complementary feeding milk before time. Special Puskesmas Larangan outside 1 and Puskesmas Prohibition 2 number of infants aged less than 6 months to October as many as 86 babies with exclusive breastfeeding coverage of 15 babies Based on the first data collection of researchers conducted in interviews on 8 mothers with infants less than 6 months in the Puskesmas Larangan Luar there are 6 mothers giving early breastfeeding mothers, the six mothers said that they gave MP-ASI when the baby was 40 days old because there was herbal medicine from infant shaman. Jamu diok given in every morning after bathing. In addition to already given herbal checks, the baby has also been given MP-ASI in the form of fine flour porridge, lontong, degan and bananas since the age of 2 months. As for the side effects occure of early breastfeeding that had occurred in the Puskesmas Larangan in 2016 is the baby 
suffered from choking because it was given a young degan food for her baby who suffered from fever and died after being referred to the hospital. In addition there is a 1-month-old baby bloated because it was spent on feeding lontong and bananas but healed after treatment at the hospital recovered (Data Bidan Puskesmas Larangan, 2017).

Many reasons why parents introduce breastfeeding MP less than 6 months of which most mothers who have the assumption if his son is hungry will not fall asleep, other than that old people in the ancient society where the child is given a banana when the age of 1 month for children not fussy and quieter. Another reason the pressure from the environment that is family (husband and parents / grandmother) who play a role in give MP ASI is also very high because it is a culture that has been hereditary. Low maternal education affects mother decision-making in giving of ASI MP to baby because of lack of knowledge about exclusive breastfeeding. Mother's work can influence early breastfeeding mothers since working mother can not give exclusive breastfeeding and added no support in breastfeeding and incessant promotion baby food manufacturers who heed the exclusive breastfeeding of 6 months (Kristianto, 2013).

Some other factors that also affect the feeding of complementary breastmilk are too early, the first is exist maternal parity reason. The second cause is exist the customs of the people in the area because it can not be denied that the customs of society that has existed since antiquity also affects the high provision of MP-ASI that is too early. Third, the existence of knowledge factors owned by mothers because the mothers assume that the baby is not satisfied if only consuming milk only and last is the existence of family support factors. Family role in the provision of MPASI> 6 months is needed, especially the culture of Indonesian society that is still collective in the family role in the pattern of child care, especially in the care of babies. Mother plays an important role in the provision of proper MP-ASI. The large number of mothers who give less than 6 months of breast milk in infants today can cause negative impacts on the health of infants such as infants become susceptible to diseases of the canines such as diarrhea. This is because the mother is less aware of the proper feeding of breastfeeding, in addition to the mother's job status is the reason that the mother provides complementary feeding too early for lack of time for her child, and the socioeconomic status of the family affects the mother to give complementary feeding too early seen from the purchasing power of breastfeeding complementary food that if the better the family economy then the purchasing power of other food is also easy (Kristianto, 2013).

The role of health workers, especially midwives, is expected to improve the quality of maternal and child health, especially in the provision of MP-ASI when it should be provided by providing counseling or counseling to breastfeeding mothers, providing help to breastfeeding mothers with satisfaction to their babies, exclusive breastfed infant races by Puskesmas by cooperating with cadres, village apparatuses and community leaders, to improve the realization of complementary feeding of timely milk.

\section{METHOD}

In this research, the research design used is "Analytic observational Cross Sectional. Cross sectional is a type of research that emphasizes the time of measurement or observation of independent variable data (knowledge, socioeconomic, cultural, role of health cadres) and dependent (early ASI feeding in infants 0-6 months) only once at one time 


\section{SPECIAL DATA}

1. Cross tabulation between Knowledge with Early Breastfeeding MP.

Table 4.1 Cross tabulation between knowledge with early breastfeeding In PuskesmasLaranganKabupatenPamekasan.

\begin{tabular}{cccccccc}
\hline \multirow{2}{*}{ Knowledge } & \multicolumn{4}{c}{ Time } & \multicolumn{2}{c}{ Total } \\
\cline { 2 - 6 } & \multicolumn{2}{c}{$\leq \mathbf{4}$ month } & \multicolumn{2}{c}{$\mathbf{4}$ month } & \multicolumn{2}{c}{} \\
\cline { 2 - 6 } & $\mathrm{f}$ & $\%$ & $\mathrm{f}$ & $\%$ & $\mathrm{f}$ & $\%$ \\
\hline Good & 1 & $1,4 \%$ & 37 & $52,1 \%$ & 38 & $53,5 \%$ \\
\hline Middle & 14 & $19,7 \%$ & 14 & $19,7 \%$ & 28 & $39,4 \%$ \\
\hline Less & 2 & $2,8 \%$ & 3 & $4,2 \%$ & 5 & $7,0 \%$ \\
\hline Total & 17 & $23,9 \%$ & 54 & $76,1 \%$ & 71 & $100.0 \%$ \\
\hline
\end{tabular}

Sumber: Data Primer, 2018

In cross-tabulation of knowledge with the provision of MP-ASI early obtained the most results is good knowledge with the provision of MP-ASI at age> 4 months ie 37 people $(52.1 \%)$.

2. Socio-economic cross-tabulation with Early Breastfeeding MP

Table 4.2 Cross tabulation between socio-economic and Early MP-Breastfeeding at Puskesmas Larangan Kabupaten Pamekasan

\begin{tabular}{cccccccc}
\hline \multirow{2}{*}{ Socio-economic } & \multicolumn{4}{c}{ Time } & \multicolumn{2}{c}{ Total } \\
\cline { 2 - 6 } & \multicolumn{2}{c}{$\leq \mathbf{4}$ month } & \multicolumn{2}{c}{ 4 month } & \multicolumn{2}{c}{} \\
\cline { 2 - 6 } & $\mathrm{f}$ & $\%$ & $\mathrm{f}$ & $\%$ & $\mathrm{f}$ & $\%$ \\
\hline Pre prosperous family & 2 & $2.8 \%$ & 22 & $31,0 \%$ & 24 & $33.8 \%$ \\
\hline Prosperous family stage I & 15 & $21,1 \%$ & 32 & $45,1 \%$ & 47 & $66.2 \%$ \\
\hline Total & 17 & $23,9 \%$ & 54 & $76,1 \%$ & 71 & $100 \%$ \\
\hline
\end{tabular}

Sumber: Data Primer, 2018

In cross-tabulation between socioeconomic and early childhood breastfeeding, the highest result was the first stage with the IV-ASI age of 4 months ie 32 people (45.1\%). 
3. Cross cultural tabulation with Early Breastfeeding of MP

Table 4.3 Cross-tabulation between Culture and Early Breastfeeding in Puskesmas Larangan Pamekasan District.

\begin{tabular}{cccccccc}
\hline \multirow{2}{*}{ CULTURE } & \multicolumn{4}{c}{ Time } & \multicolumn{2}{c}{ Time } \\
\cline { 2 - 6 } & \multicolumn{2}{c}{$\leq \mathbf{4}$ month } & \multicolumn{2}{c}{$\leq \mathbf{4}$ month } & \multicolumn{2}{c}{} \\
\cline { 2 - 6 } & $\mathrm{f}$ & $\%$ & $\mathrm{f}$ & $\%$ & $\mathrm{f}$ & $\boldsymbol{\%}$ \\
\hline Culture & 4 & $5,6 \%$ & 44 & $62,0 \%$ & 48 & $67,6 \%$ \\
\hline Dont Embrace Culture & 13 & $18,3 \%$ & 10 & $14.1 \%$ & 23 & $32,4 \%$ \\
\hline Total & 17 & $23,9 \%$ & 54 & $76,1 \%$ & 71 & $100 \%$ \\
\hline
\end{tabular}

Sumber: Data Primer, 2018

In cross-tabulation between cultures with the provision of early breast milk-feeding, the most common result was adhered to the provision of MP-ASI age> 4 months ie 44 people $(62 \%)$.

4. Cross tabulation The role of health cadres with early breastfeeding

Table 4.4 Cross tabulation between the role of health cadres with the provision of early breastfeeding at the Puskesmas Larangan Pamekasan District.

\begin{tabular}{cccccccc}
\hline \multirow{2}{*}{ The Role Of Health Cadres } & \multicolumn{4}{c}{ Time } & \multicolumn{2}{c}{ Total } \\
\cline { 2 - 6 } & \multicolumn{2}{c}{$\mathbf{5}$ month } & \multicolumn{2}{c}{$\leq \mathbf{4}$ month } & \multicolumn{2}{c}{} \\
\cline { 2 - 7 } & $\mathrm{f}$ & $\%$ & $\mathrm{f}$ & $\%$ & $\mathrm{f}$ & $\%$ \\
\hline Good & 5 & $7,0 \%$ & 29 & $40,8 \%$ & 34 & $47,9 \%$ \\
\hline Moderat & 8 & $11,3 \%$ & 17 & $23,9 \%$ & 25 & $35.2 \%$ \\
\hline Less & 4 & $5,6 \%$ & 8 & $11.3 \%$ & 12 & $16,9 \%$ \\
\hline Total & 17 & $23,9 \%$ & 54 & $76,1 \%$ & 71 & $100 . \%$ \\
\hline
\end{tabular}

Sumber: Data Primer, 2018

In cross-tabulation between cadre roles with the provision of early breastfeeding, the highest result was good with IV-ASI infant feeding> 4 months ie 29 people (40.8\%).

5. Multivariable Statistics Test with Logistic Regression

a. Statistical test of the relationship of all independent variables with the dependent variable

Table 4:5 Regression test results Logistics relationships variables are all independent with the dependent variable

\begin{tabular}{|c|c|c|c|c|c|c|c|}
\hline & & B & S.E. & Wald & df & Sig. & $\operatorname{Exp}(B)$ \\
\hline Step 0 & Constant & -1.156 & .278 & 17.271 & 1 & .000 & .315 \\
\hline
\end{tabular}

Sumber: Data Primer, 2018

Based on the statistical test results obtained $\mathrm{pF}$ test value of $0.000(<0.005)$, then the null hypothesis is rejected which means that the overall independent variable has a linear relationship with 
the dependent variable.Secar together knowledge, socioeconomic, cultural and cadre role related to the giving of MP Early.

b. Statistical Test of the most dominant independent variable with the dependent variable

Table 4:6 Logistic regression test results independent variable relationship with the dependent variable.

\begin{tabular}{cccccccc}
\hline & & B & S.E. & Wald & df & Sig. & Exp(B) \\
\hline \multirow{3}{*}{ Step $1^{\mathrm{a}}$} & Knoeledge & 1.315 & .623 & 4.456 & 1 & .035 & 3.725 \\
\cline { 2 - 8 } & Socialeconomi & 1.441 & .964 & 2.233 & 1 & .135 & 4.226 \\
\cline { 2 - 8 } & Culture & 2.300 & .780 & 8.695 & 1 & .003 & 9.973 \\
\cline { 2 - 8 } & Role of pastient & .783 & .522 & 2.248 & 1 & .134 & 2.187 \\
\cline { 2 - 8 } & Constant & -10.784 & 2.890 & 13.923 & 1 & .000 & .000 \\
\hline
\end{tabular}

c. Variable(s) entered on step 1: pengetahuan, sosialekonomi, sosbud, perankader.

Based on the table coefficient $\mathrm{p}$-value for cultural and knowledge variables $<0.005$ so that the two variables are related to early breastfeeding. Sedangkan health role Kader roles have p-value 0.134 (>0.005) and socioeconomic p-value value 0.135 (> 0.005), so that the null hypothesis is accepted, which means that the role ratios of health and social cadres are not related to early breastfeeding.

Based on these results the largest or dominant influence lies in the sociocultural variables with a large $p$-value $=0.003$. So it can be concluded that the most dominant reason affecting the provision of early breast milk is a cultural factor.

\section{DISCUSSION}

\section{A. Influence of Mother Knowledge of Early Breastfeeding MP in 0-6 months old baby at PuskesmasLaranganPamekasan district.}

Based on the results of this study show that from 71 respondents most of the knowledge of mother good with giving of ASI MP at infant age 4 months $(52,1 \%)$, and result of Logistic Regression test got that $\mathrm{p}$ value $=0,035$ with $\mathrm{OR}=3,725$. This means that if the mother's knowledge is good about the provision of early breastmilk MP then the opportunity to give early breast milk in infants aged $>4$ months is 3.725 times greater than mothers who have less knowledge. Because the value of $\mathrm{p}<0.05$, so that Ho is rejected and $\mathrm{H} 1$ accepted which means there is influence of mother's knowledge with the provision of Early Breastfeeding MP in Infants aged 0-6 months in PuskesmasLaranganPamekasan District

The results of this study are similar to the results of earlier research, a study conducted by Setyaningsih (2010) whose results show a significant relationship of knowledge of mothers with the provision of MP ASI Dini $(p=0.03)$. Results of another study conducted by Dwiyanti (2016) the results showed there was a significant relationship between knowledge with the provision of MP ASI $(\mathrm{p}=0.038)$.

Knowledge is the result of knowing, and this happens after people have sensed a particular object. Sensing occurs through the human senses, namely the sense of sight, hearing, smell, taste and touch (Notoatmodjo, 2012). Knowledge or cognitive is a very important domain for the formation of one's actions (overt behavior) (Notoatmodjo, 2010). Most knowledge is acquired through the eyes and ears. Health behavior is also influenced by knowledge as a predisposing cause. If knowledge about complementary supplements of breast milk is also expected in the end the behavior towards complementary feeding is also good.

From the results of data collection of mother's knowledge questionnaire about ASI MP almost completely understand and answer that MP ASI is as food substitute of breast milk so that they assume that baby only given milk is not enough. In addition almost half of the respondents also do not 
understand the signs of the baby is ready to be fed complementary foods such as the baby can stand up and have been able to sit while supported, which in theory the motor development can be achieved children aged 4-6 months, those who give it with sleeping place while being fed is giving the child to eat with the position of sleeping lying on both legs of the mother's leg then body and hands tied up with a sling backward so that when fed not motion. This gesture is mostly done by the mother when the baby is aged 2 to 3 months ie in the form of lontong or rice crushed mixed with bananas. One of the impacts that can occur due to this behavior is to make babies choke, The behavior of the mother occurs because of ignorance about how to give MP ASI correctly. This is in accordance with the journal Pajriyani and Kuswandi (2013) which states that maternal knowledge affects the mother in giving the ASI to her baby. Thus, knowledge has a positive impact on breastfeeding mothers who give right feeding of breastmilk. breastfeeding mothers, low knowledge of complementary feeding in infants 0-6 months.

\section{B. Effect of social economy on giving Early Breastfeeding MP in infants aged 0-6 months in PuskesmasLaranganPamekasan.}

Based on the results of this study showed that from 71 respondents almost half of the socioeconomic conditions stage I with giving early MP-ASI at age> 4 months ie 32 people $(45.1 \%)$. , and Logistic Regression test results obtained that the value $\mathrm{p}=0.135$ with $\mathrm{OR}=4,226$. This means that if the social economy of the mother who gives MP ASI. I then the opportunity to give early breastmilk MP in infants aged $>4$ months of 4.226 times greater than mothers who have the social economic pre-prosperous stage. Because the value $p>0.05$, so Ho accepted and H1 rejected which means there are no social-economic influences of mothers with the provision of MP ASI Early in Infants aged 0-6 months in PuskesmasPuskesmasPamekasan.hal this may be due to the character of most respondents is homogeneous, mostly work as farmers and private.

The results of the study also showed that $71 \%$ of respondents studied were mostly (51\%) of mothers employed as farmers and IRT and almost half were private (49\%) where most private duties (70\%) indicated that most mothers had activities at home and partly outside the home to help the husband work private (trade) with income that does not settle each monthly.Dalam this case the length of the mother to leave the baby can be the reason for early breastfeeding so that for those who have a baby to overcome it usually they replace Exclusive breastfeeding with formula milk, but for housewives it is also possible to give inappropriate breast milk in terms of time, type, and way because it is also influenced by local cultural beliefs. In addition, they have also facilitated in terms of types of complementary foods provided ASI most of the crops and gardens themselves such as rice cooked with banana, brown rice porridge and rice stew water for the reason that the texture is softer and softer so easily digested by the baby. With the feeding of MP ASI, parents assume will increase the growth and development of the baby. In this study, all respondents gave MP ASI early on $(76,1 \%)$ gave by the time the baby was $>4$ months old.

The results of this study are similar to the results of earlier research, a study conducted by IsnaHikmawati (2008) whose results show no significant relationship between social economics with breastfeeding $(\mathrm{p}=0,512)$. Welfare economics is the framework used by most public economists to check the income society wants (Rosen, 2005: 99).

\section{Cultural Effect on Early Breastfeeding MP in 0-6 months old infants at PuskesmasLaranganPamekasan district.}

Based on the results of this study shows that of 71 respondents mostly embraced culture with the provision of MP-ASI age> 4 months ie 44 people (62\%)., And Logistic Regression test results obtained that the value $p=0.003$ with $\mathrm{OR}=9.973$. This implies that if the mother embraces the culture of early breastfeeding, the chances of giving breast milk MP early in infants aged $\leq 4$ months is 9.973 times greater than mothers who have no culture. Because the value of $\mathrm{p}<0.05$, so that Ho is rejected and $\mathrm{H} 1$ accepted which means there is a cultural influence with the provision of Early Breastfeeding MP on Infants aged 0-6 months in PuskesmasLaranganPamekasan District.

The results of this study are similar to earlier studies. This study was conducted by Rahmaliaafriyani, ShintyaHalisa and HettyRolina (2016) where the results indicate a significant 
relationship between culture or tradition with the provision of MP ASI in infants aged 0-6 months $(\mathrm{p}=$ 0.004 ). Other research conducted by DaulatGinting, and NananSekarwarna, and HadyanaSukandar (2012) showed that there was a significant correlation between cultures with the provision of MP ASI Dini in infants aged $0-6$ months $(\mathrm{p}=0.001)$.

From the result of tabulation between the culture with giving of ASI MP get most of the mother embrace culture or tradition in giving of ASI by giving it at baby age > 4 months. From a result of questionnaire data collecting almost all mother assume that baby that given MP ASI will grow healthy, fast fat and plump because breast milk alone is not enough. In line with the results of this study Utami (2014) states that social culture or tradition has a relationship with the provision of early breastfeeding MP, some people still think that in the provision of MP ASI in children due to fussy children, who works to help her husband earn a living, and still holds a strong tradition of ancestors. Types of MP ASI given in general are some instant foods such as red rice porridge and part of their own crops such as bananas, crushed rice, formula, and honey. The reason the mothers give the breast milk to their children is that of fuss or cry that he considered because hunger and the influence of parents who ancient to give complimentary food at an early age to be fulfilled all the needs of the child.Tradisi family in the provision of MP ASI is usually handed down by parents to their children such as giving bananas, team rice, honey, water and so forth.The mindset of people who still trust it can accelerate the growth of babies will follow the tradition as a form of obedience to the parents.

\section{Influence of health cadre role on giving of early breast milk in infants aged 0-6 months in Puskesmas Larangan Pamekasan district}

Based on the results of this study showed that of 71 respondents almost half the role of health cadres Good with the provision of MP-ASI baby age> 4 months ie 29 people (40.8\%), and Logistic Regression test results obtained that the value $\mathrm{p}=0.134$ with $\mathrm{OR}=2.187$. This means that if the role of health cadres is good then the chances of giving early breast milk MP in infants aged $>4$ months is 2.187 times greater than the role of health cadres are less Because p> 0,05, so Ho accepted and $\mathrm{H} 1$ rejected which means there is no influence of health cadre's role by giving early breastfeeding to infants aged 0-6 months in PuskesmasLaranganPamekasan.Hal this may be due to the role of the cadre that is not specific to the problem of ASI MP but the role of cadres in general so that although the role of health cadres either does not affect the mother's behavior in the provision of early breast milk MP.

The results of this study are similar to those of earlier research. Research conducted by Linda YunusUsman, Hesty Lestari (2013), where the results showed no significant relationship of health cadre role with exclusive breastfeeding $(\mathrm{p}=0,057)$.

A health worker is a person who is responsible for providing health services to people, families, and communities. There are two aspects of health service quality that need to be done in Puskesmas that is quality of care and quality of service. quality of care includes the technical skills of health workers in diagnosing and providing care to the patient, while the quality of service concerns how health workers give health information services (Munijaya, 2011). While according to Potter \& Perry (2011) the role of health workers is as customer service, communicators, motivators, facilitators, and counselors. As a motivator health officer should be able to provide encouragement to patients to behave healthily to make optimal health. And the counseling of health officers is expected to create behavioral changes carried out individually or in groups through effective communication to express the problems according to the condition of the patient until the patient feels the problem and guide in the implementation (Mandriwati, 2010).

Health workers have an important role in providing health services, especially in providing motivation and counseling to breastfeeding mothers to continue trying to exclusively breastfeed their babies. Increasing the provision of MP ASI too early will have adverse effects, one of which is digestive disorders in infants such as diarrhea, vomiting and difficult bowel movements (Cott, 2013). Besides, complementary feeding of ASI will also affect the level of intelligence of the brain after adulthood such as triggering the occurrence of obesity disease, hypertension and coronary heart disease (Nadesul, 2005). 


\section{E. The most dominant factors that affect the provision of early MPASI in infants aged 0-6 months in Puskesmas Larangan Pamekasan district}

Based on the result of statistical test of logistic regression got value on cultural cause $p=$ 0,003 ; $\mathrm{OR}=9,973$ and on knowledge cause $\mathrm{p}=0,035 ; \mathrm{OR}=3,725$. This implies that if the mother embraces the culture of giving early breastfeeding to her baby, then the mother is at risk of giving her breast milk MP at her $\leq 4$-month-old 9.973 times greater than the non-cultured mother. If the mother has good knowledge about giving ASI MP, then the mother's risk to give ASI early on when the baby is> 4 months 3,725 bigger than the mother having knowledge less. So it can be concluded that the most dominant factor affect $\mathrm{Y}$ (giving of ASI Early) is a cultural factor with an influence of 9,973 times.

The results of this study differ from the results of earlier research conducted by Dwiyanti (2016) which results show that the most dominant factor affecting the provision of MP ASI in infants aged 6-9 months is the job $(\mathrm{p}=0.035)$. The results of this study also differ from the results of the IsnaHikmawati (2008) study, where the results show the most dominant factors that most influence the risk of failure of breastfeeding for two months is the mother's job ( $\mathrm{p}=0,001$; OR $=3,31)$. Other studies were also different where the most dominant factor had an effect on the provision of early breast milk in infants aged less than 6 months was knowledge $(p=0,004)$ (RinaHarwati, 2016).

Breast Milk or breast milk is a nutrient that is able to meet all the nutritional elements for the development of the baby into a healthy and intelligent child (Roesli U, 2014). Exclusive or more appropriate exclusive breastfeeding is the baby is given only breast milk without other fluids such as infant formula, oranges, honey, tea water, water, and without the addition of solid foods such as bananas, papaya, milk porridge, biscuits, rice porridge, and teams (Roesli U, 2014)) should be ready since the fetus is still in the womb, taking care of the breast during pregnancy, especially at 2-3 months before the mother gives birth. Breastfeeding time is as early as and as often as possible until a 2-year-old child (Hayati A, 2010). Early exclusive breastfeeding is recommended for at least 4 months, but if possible for up to 6 months. After 6 months of age, with solid foods, while breast milk can be given to infants aged 2 years or even more than 2 years (Roesli U, 2014).After 6 months of age, the baby is not only given breast milk alone, but the baby also needs to be given MPASI or breastfeeding companion to meet nutritional intake. MPASI or breastfeeding complementary foods are foods given to infants aged 6 months and over (Sutomo B, 2013). The most dominant factor affecting mother's behavior in giving of ASI MP is local culture/habit on early breastfeeding of MPASI which has not supported the implementation of Exclusive Breastfeeding. These habits or traditions that may be factors that influence the knowledge of the family, both mother, father-in-law, and husband to give breastfeeding premature dating from generation to generation (Yeni and Minsarnawati, 2009).

\section{CONCLUSION}

1. There is an influence of knowledge on the provision of early breast milk in infants aged 0-6 months in PuskesmasLaranganPamekasan $(\mathrm{p}=0,035$; OR $=3,725)$.

2. There is no socio-economic influence on early breastfeeding of infants at 0-6 months of age at PuskesmasLaranganPamekasan $(\mathrm{p}=0,135 ; \mathrm{OR}=4,226)$.

3. There is a cultural influence on the provision of early breast milk in infants aged 0-6 months in PuskesmasLaranganPamekasan District ( $\mathrm{p}=0,003$; OR $=9,973)$.

4. No influence The role of health cadres in the provision of early breast milk in infants aged 0-6 months in PuskesmasLaranganPamekasan District $(\mathrm{p}=0.134$; $\mathrm{OR}=2.187)$.

5. The most dominant factor influencing the giving of early breast milk in infants aged 0-6 months in PuskesmasLaranganPamekasan is Culture $(\mathrm{p}=0,003$; OR $=9,973)$. 


\section{SUGGESTION}

1. For the respondent

For breastfeeding mothers is the most important and most important factor in the success of exclusive breastfeeding, breastfeeding mothers need to be aware of the importance of exclusive breastfeeding, the risk of breastfeeding supplements before 6 months of age, and should also consult a health worker if there are health-related problems time of early breastmilk feeding.

2. For Research Sites (Puskesmas Larangan Kabupaten Pamekasan)

Continue to make educational efforts or health promotion and counseling to pregnant or breastfeeding mothers and their families so that they understand when the right time to give breastfeeding MP and its impact if given early breast milk MPI.

3. For educational institutions

Continue to conduct research on breastfeeding supplementary feeding in infants in particular how to optimize breastfeeding mothers' awareness to exclusively breastfeed.

4. For further researchers

Given the limitations of the research, it is hoped that the next researcher will develop this research by examining the wider variables of family knowledge and the role of special health cadres in the provision of early breast milk.

\section{REFERENCE}

Arikunto, S. (2010). Prosedur Penelitian Suatu Pendekatan Praktik, Edisi Revisi. Surabaya: Renika Cipta.

Atik Setyaningsih. (2010). Hubungan karakteristik ibu dengan pemberian MP ASI dini pada bayi O-6 bulan di Posyandu Warna Sari Desa Glonggong Nogosari Boyolali, jurnal Kebidanan, Vol II, No 1, Juni 2010.

Cott, P. W. (2012). Seri Budaya Anak, Makanan Sehat untuk Bayi dan Balita. Jakarta: Dian Rakyat.

Depkes RI. (2006). Pedoman Pelaksanaan Pendistribusian dan penelolaan makanan pendamping air susu ibu. Tahun 2004. Jakarta: Direktorat Jendral Gizi Masyarakat.

Departemen Kesehatan Republik Indonesia. (2010). Persen Bayi Memperoleh MP ASI dini Diambil 23 Oktober 2016 dari http://www.depkes.go.id/index.php?ption=news\&task=viewarticle\&sid=2008.

Dinkes. Pamekasan. (2011). jumlah bayi yang mendapatkan ASI Eksklusif.

Donna, L., Wong. (2010). Buku Ajar Keperawatan Pediatri Edisi 6. Jakarta: EGC.

Ekerette Emmanuel Udoh. (2016). Complementary feeding practicesamong mothers and nutritional status of infantsin Akpabuyo Area, Cross River State Nigeria.

Hayati, A. (2010). Buku Saku Gizi Bayi. Jakarta: Penerbit Buku Kedokteran EGC. Pengantar Ilmu Keperawatan Anak 1. Jakarta: Salemba Medika.

Hoiroh. (2017). Hubungan Dukungan Suami dengan Pemberian ASI Eksklusif pada Ibu Menyusui di BPM Siti Huzaimatul Himmah Bugih Pamekasan, Skripsi.

Indriyawati.

(2010).

http://digilib.unimus.ac.id/files/disk1/133/jtptunimusgdlerlinaw

-6603-3-babii.pdf.(Hal : 15). 
Irawati, A. (2010). Stop MP-ASI Terlalu Dini.http://www.parenting.co.id./ (Diakses pada tanggal 08-11-2017 pukul 11.30 WIB).

Isna, Hikmawati. (2008). faktor-faktor Resiko Kegagalan Pemberian ASI Selama 2 Bulan di Kabupaten Banyumas, tesis.

Lis Dwiyanti. (2016). Faktor - faktor yang berhubungan dengan pemberian MPASI pada bayi usia 6 - 9 bulan Di Kelurahan Sorosutan Kota Yogyakarta.

Nadesul, SH. (2005). Makanan Sehat Untuk Bayi. Jakarta: Puspa Swara.

Nina, Nirmaya, Mariani. (2016). Faktor - faktor yang berhubungan dengan pemberian MP ASI dini di wilayah kerja UPTD Puskesmas Sindanglau Kecamatan Lemah abang Kabupaten Cirebon, jurnal Kesehatan, volume VII, nomor 3, November 2016, hlm 420 - 426.

Notoadmojo. (2012). Pendidikan dan Pemberian ASI. Rineka Cipta. Jakarta.

Nursalam. (2016). Penerapan Metodologi Penelitian Keperawatan. Jakarta. Salemba Medika.

Perry, \& Potter. (2010). http://repository.usu.ac.id/bitstream/123456789/27110/4/Chapter\%20II.pdf. (Hal : 01).

Rina Harwati. (2016). faktor - faktor yang mempengaruhi ibu menyusui dalam memberikan MP ASI terlalu dini pada bayi usia kurang 6 bulan dikelurahan Giritirto Kabupaten Wonogiri.

Risa Wargiana. (2013). Hubungan Pemberian MP ASI Dini dengan status gizi bayi umur 0 -6 bulan Di Wilayah kerja Puskesmas Rowotengah kabupaten Jember, Jurnal Pustaka kesehatan, Vol 1 (No. 1) September 2013.

Rorohany, Nursitoresmi. (2014). gambaran karakteristik ibu yang memberikan MP ASI pada bayi 0 - 6 bulan di Desa Jati Kecamatan Jati Kabupaten Blora.

Roesli, U. (2014). Mengenal ASI Eksklusif. Jakarta: Trubus Sgriwidya.

Shuchita, Gupta., \& Ramesh, Agarwal. (2017). Complementary feeding at 4 versus 6 months of age for preterm infants born at less than 34 weeks of gestation: a randomised, open-label, multicentre trial.

Sugiyono. (2010). Metode Penelitian Pendidikan Pendekatan Kuantitatif, Kualitatif dan R\&D. Bandung: Alfabeta.

Suhita, Byba Melda. (2017). Metodologi penelitian Kesehatan. Ponorogo. Forum Ilmiah Kesehatan (FORIKES).

Sulistyoningsih. (2016). faktor - faktor yang berhubungan dengan waktu pemberian MP ASI Dini pada bayi usia 6-9 bulan, Yogyakarta: Skripsi.

Supariasa. (2011). Asuhan Keperawatan bayi dan Anak Edisi Pertama. Jakarta: Salemba Medika.

Sutomo, B. (2013). Menu Harian MPASI - Menu Sehat \& Alami. Jakarta Selatan: PT. Trans Media.

World Health Organization. (2014). Principles for Complementary Feeding of the Breastfed Child. Washington D. C: PAHO.

Yuliarti, N. (2010). Keajaiban ASI - Makanan Terbaik untuk Kesehatan, Kecerdasan, dan Kelincahan Si Kecil. Yogyakarta: C.V. Andi Offset. 